\title{
Hieroglyphic Moth, Diphthera festiva (Fabricius) (Insecta: Lepidoptera: Noctuidae) ${ }^{1}$
}

James C. Dunford and Kathryn A. Barbara²

\section{Introduction}

The hieroglyphic moth, Diphthera festiva (Fabricius), is distributed throughout Florida and tropical or subtropical regions of the New World. The conspicuous larvae often occur gregariously on a wide array of plant species and occasionally are considered pests of pecan, coconut palms, sweet potato and soybeans.

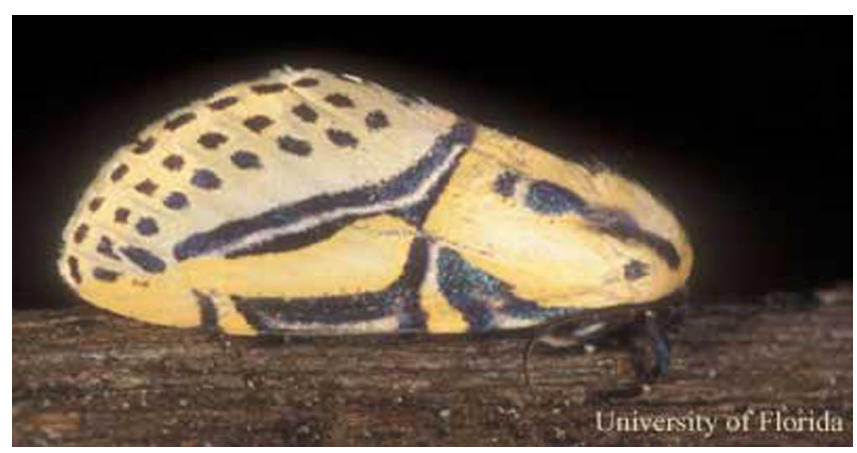

Figure 1. Adult hieroglyphic moth, Diphthera festiva (F.). Credits: Photograph by: Lyle Buss, University of Florida

\section{Synonymy}

Synonymy (from Heppner 2003)
Diphthera Hübner (1809)

Euglyphia Hübner (1820)

Diphtera Stephens (1850, emend.)

Noropsis Guenée (1852)

festiva (Fabricius) (1775)

hieroglyphica (Cramer 1777, preocc. [not Drury 1773])

elegans Hübner (1809)

fastuosa Guenée (1852)

\section{Distribution}

The hieroglyphic moth, originally described from Central and South America, is known to occur throughout tropical and subtropical areas of South America (as far south as Bolivia and Brazil), Central America, North America, and the Caribbean. In North America, the species has a southeastern distribution from South Carolina west to Texas along

1. This document is EENY-326, one of a series of Featured Creatures from the Entomology and Nematology Department, Florida Cooperative Extension Service, Institute of Food and Agricultural Sciences, University of Florida. Published: May 2004. This document is also available on Featured Creatures Website at http://creatures.ifas.ufl.edu. Please visit the EDIS Website at http://edis.ifas.ufl.edu. Additional information on these organisms, including many color photographs, is available at the Entomology and Nematology Department website at http://entnemdept.ifas.ufl.edu/.

2. James C. Dunford and Kathryn A. Barbara, Department of Entomology and Nematology, University of Florida, Gainesville, FL.

The Institute of Food and Agricultural Sciences is an equal opportunity/affirmative action employer authorized to provide research, educational information and other services only to individuals and institutions that function without regard to race, color, sex, age, handicap, or national origin. For information on obtaining other extension publications, contact your county Cooperative Extension Service office. Florida Cooperative Extension Service/Institute of Food and Agricultural Sciences/University of Florida/Christine Taylor Waddill, Dean. 
the Gulf Coast. Strays have been recorded as far north as Michigan and Missouri (Covell 1984). It occurs throughout Florida (Holland 1903, Covell 1984, Weston and Whalley 1975).

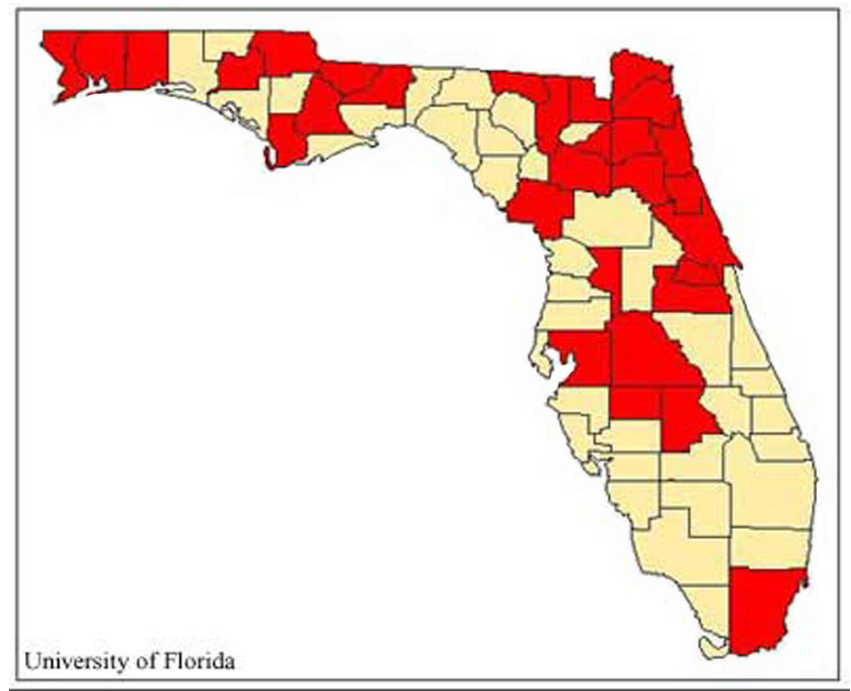

Figure 2. County records (in red) of the hieroglyphic moth, Diphthera festiva (F.) in Florida based on label data taken from specimens examined in the Florida State Collection of Arthropods (FSCA). April 2004. Credits: Illustration by: Kathryn A. Barbara, University of Florida

\section{Larval records from FSCA:}

\section{Florida:}

Alachua Co. - Archer, Gainesville; Baker Co. Macclenny; Bradford Co. - Brooker; Clay Co.; Dade Co. - Miami; Escambia Co. Molino, Cantonment; Flagler Co.; Gadsden Co. - Quincy; Gulf Co. Apalachicola; Hardee Co. - Highlands Co. - Avon Park; Hillsborough Co. - Plant City; Jackson Co. Marianna, Graceville; Leon Co.; Levy Co. Williston; Nassau Co. - Callahan; Okaloosa Co. Milligan; Orange Co. - Winter Garden; Polk Co. Santa Rosa Co.; Seminole Co.; Washington Co.

\section{Georgia:}

Effingham Co.

\section{Costa Rica:}

Guanacaste Province, Liberia

\section{Ecuador:}

Los Rios Province, Quevedo

\section{Adult records from FSCA:}

\section{Florida:}

Alachua Co. - Gainesville; Columbia Co.; Duval Co. - Jacksonville; Hamilton Co. - Jasper, White Springs, High Springs; Highlands Co. - Sebring, Lake Placid; Hillsborough Co. - Temple Terrace; Leon Co.; Liberty Co. - Torreya State Park; Monroe Co. - Key Largo; Okaloosa Co. - Ocean City, Shalimar; Putnam Co.; St. John's Co. - St. Augustine; Sumter Co.; Volusia Co. - New Smyrna

\section{Georgia:}

Lowndes Co. - Valdosta; Wayne Co. - Jessup

\section{Louisiana:}

Ascension Parish - Prairieville; East Baton Rouge Parish - Baton Rouge; Iberville Parish - Sunshine; Lafourche Parish - Cutoff; St. John's Parish - Edgard; St. Tammany Parish - Abita Springs

\section{Bahamas:}

Big Wood Cay

\section{Mexico:}

Mazatlan, Sinaloa

\section{Description}

Adult hieroglyphic moths are relatively uniform in coloration throughout their range. Adults are colorful, medium sized moths with lemon yellow forewings with an elaborate pattern of metallic bluish gray lines and three rows of dots parallel to the external margin. The pronotum is lemon yellow with metallic bluish gray lines and the abdomen is black. The hindwings are dark gray in color with pale cilia, or hairs, along the edges. Adult wingspan is approximately 3.7 to $4.8 \mathrm{~cm}$.

Larvae have white to cream colored bodies with a series of transverse black bands on the dorsal side with three or four distinct black bands to each segment, one of these bands being more conspicuous. The transverse stripes do not go around the entire 


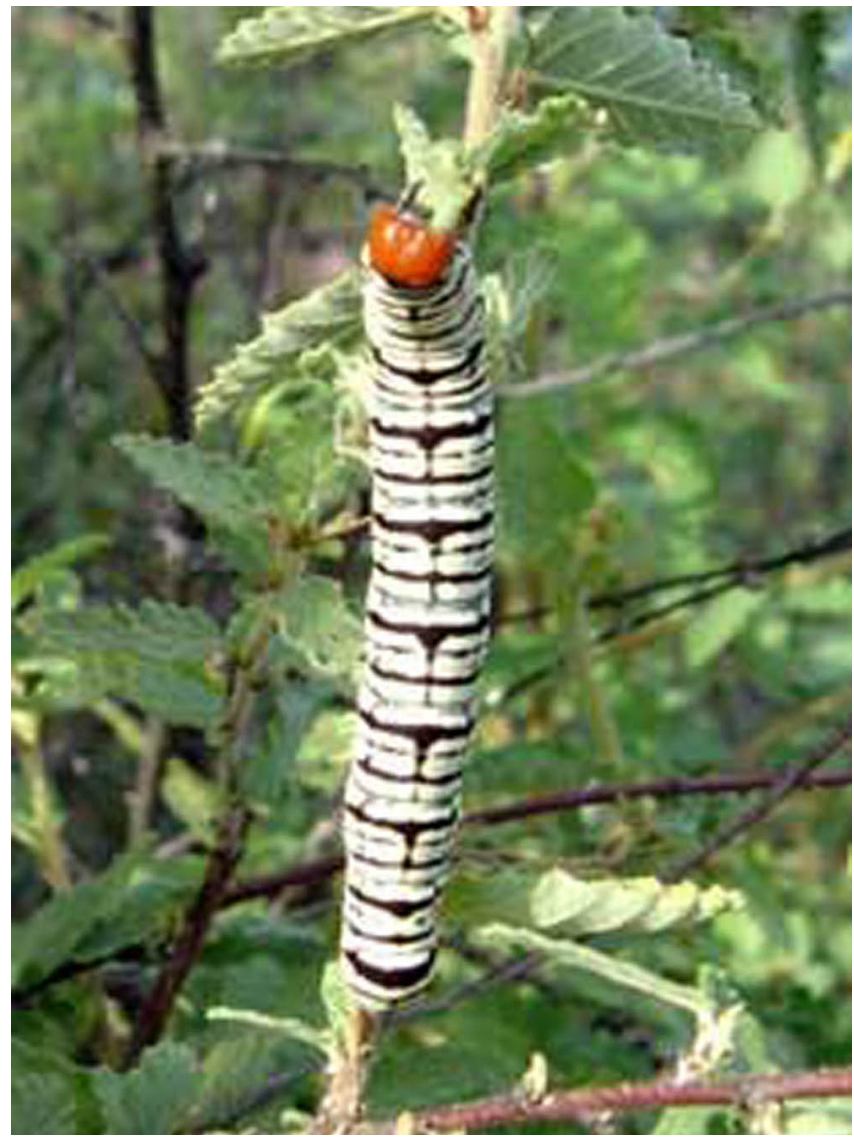

Figure 3. Larva of hieroglyphic moth, Diphthera festiva (F.) on Melochia tomentosa L., US Virgin Islands $1 / 2$ mile N. of St. Croix, Buck Island, Buck Island Reef National Monument. Credits: Photograph by: James C. Dunford, University of Florida

body but rather they end in a ventrolateral longitudinal black stripe below the spiracles. The spiracles are surrounded by black coloration and resemble small black dots. The ventral portion of the abdomen is white with black thoracic and abdominal legs. The head capsule and anal plate located on the last abdominal segment are orange-red in color. Late instar larvae are approximately $4.5 \mathrm{~cm}$ long and 0.7 cm wide.

The pupa of the hieroglyphic moth is dark brown to black with the ventral part of abdominal segments lighter in coloration. The cremaster (a cluster of small hooks used to grip substrates for pupal support in Lepidoptera) has two spine-like processes extending out approximately 45 degrees. The oval cocoon is made out of thin, coarse silk with fragments of leaves and other plant debris and are spun in the crotches of trees. The pupa ranges in size from 1.5 to $1.7 \mathrm{~cm}$ in

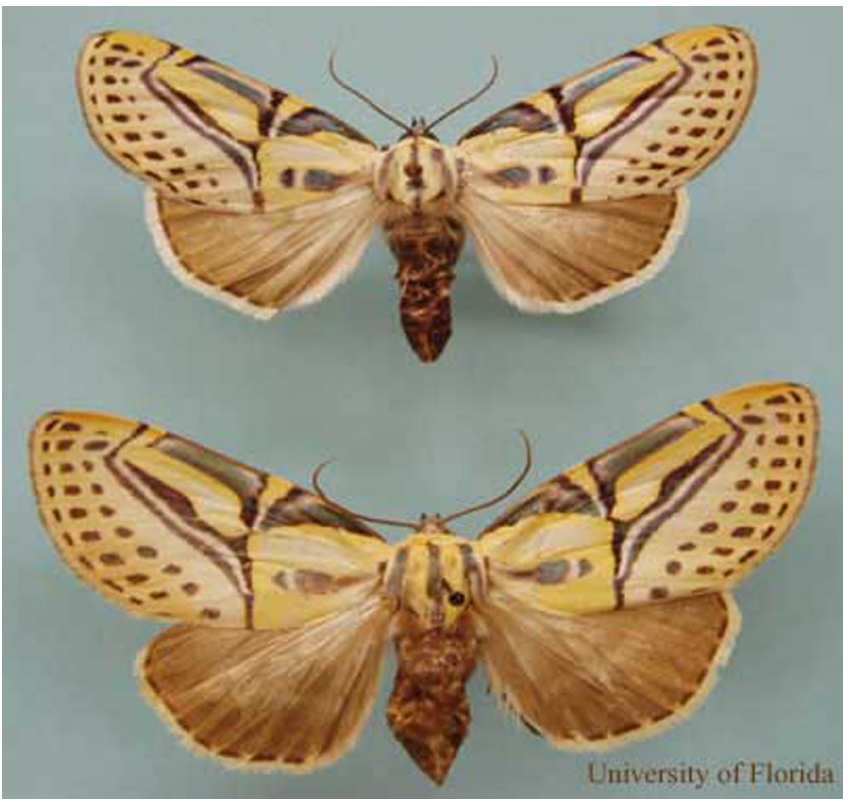

Figure 4. Adult male (top) and female of the hieroglyphic moth, Diphthera festiva (F.). Male collected from Okaloosa Co. Florida, female from Alachua Co., Florida. Credits: Photograph by: Dan Clark, Florida/Caribbean Exotic Plant Management Team (FCEPMT), National Park Service

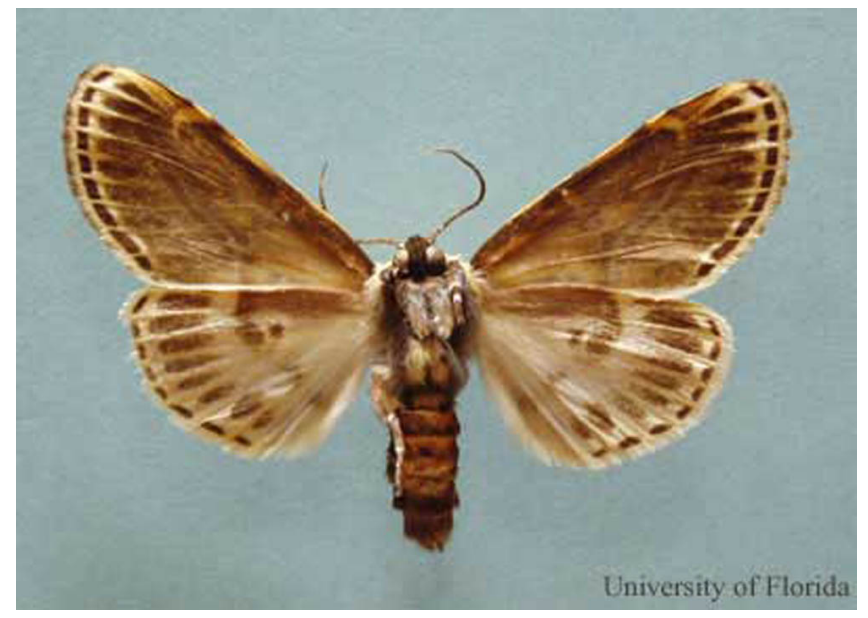

Figure 5. Underside of an adult male hieroglyphic moth, Diphthera festiva (F.), collected from Abita Springs, Louisiana. Credits: Photograph by: James C. Dunford, University of Florida

length. (descriptions taken from Benjamin 1922, Covell 1984, Becker \& Miller 2002).

\section{Life History}

Covell (1984) notes adults locally common and present from April through November in Gulf States. Based on label data on specimens housed in the FSCA, larvae appear to be present late summer and fall and adults are common during summer months in 
Florida and other southern states. It is not known how many generations complete development each year, but both larvae and adults do occur over the same months based on these label data.

A parasitic wasp in the family Chalcididae was found on a D. festiva larva on mint in Venezuela (Teran 1980). The aposematic coloration of the larvae may be a warning sign of toxicity to birds, which have been observed feeding on the larvae and immediately spitting them out (Collins \& Watson 1983, Becker Miller 2002).

\section{Host Plants}

Hieroglyphic moth larvae feed mainly on plants in the families Sterculiaceae, Fabaceae and Malvaceae. Host plant records include:

Sterculiaceae: Melochia corchorifolia L. (chocolateweed), M. pyrimidata L. (pyramid flower), M. tomentosa L. (teabush, broomwood), Waltheria indica L. (sleepy morning), and Helicteres mexicana

Fabaceae: Lespedeza thunbergii (de Candolle) Nakai (Thunberg's lespedeza), Glycine max L. (soybean), and Schrankia portoricensis Urb.

Malvaceae: Malvastrum spicatum aut. non (L.) Gray and Sida sp. in lab rearings (Collins and Watson 1983, FDACS-DPI 1983, Poole 1989, Drees and Rice 1990, Zhang 1994, Becker and Miller 2002, Heppner 2004)

Other host plants mentioned in the literature include: Phyllanthus latifolius (Euphorbiaceae) (Heppner 2004), Boerhaavia diffusa (Nyctaginaceae) (Collins \& Watson 1983), Morongia leptoclada Cook \& Collins (Mimosaceae) (Poole 1989, Zhang 1994), Carya spp. (Juglandaceae) (Poole 1989, Watson \& Whalley 1975), Ipomoea batatas (L.) Lam. (Convolvulaceae) (Poole 1989), Cocos sp. (Arecaceae) (Watson \& Whalley 1975), Casuarina equisetifolia L. (Casuarinaceae), Corchorus hirsutus L. (Tiliaceae) (Becker \& Miller 2002), and Lippia alba (Labiatae) (Teran 1980), and Solanum sp. (Solanaceae) (Dyer 1995).

\section{Damage}

Hieroglyphic moth larvae may cause damage by chewing gregariously on the leaves of the host plants. The larvae have the potential to become economic pests of economic crops such as pecan, soybean, and sweet potato. They were reported as 'infestation heavy' on the leaves of Waltheria in Miami by the Florida Bureau of Entomology in 1983 and taken in good numbers on soybean in Texas (Drees and Rice 1990).

\section{Management}

Sampling: Periodically examine leaves for hieroglyphic moth caterpillars. Direct observation of larvae on the plant during the early stages of growth is the best sampling option due to the plant's small size. Adult moth populations can be sampled using a blacklight. Once moths are detected, searching for eggs and larvae is the next step.

Insecticides: Larvae can be sprayed with a bacterial spray, or more immediate results can be obtained from the application of various pesticides. Bacillus thuringiensis, a microbial insecticide, is a bacterium that kills only lepidopteran larvae. It has no known toxicity toward beneficial insects. When using an insecticide, target young caterpillars when they are the most vulnerable to chemical control.

Insect Management Guide for Landscape Plants (http://edis.ifas.ufl.edu/IG013)

Insect Management Guide for Sweet Potatoes (http://edis.ifas.ufl.edu/IG159)

Insect Management Guide for Soybeans (http://edis.ifas.ufl.edu/IG064)

Insect Management Guide for Pecans (http://edis.ifas.ufl.edu/IG077)

\section{Selected References}

Becker VO, Miller SE. 2002. The large moths of Guana Island, British Virgin Islands: A survey of efficient colonizers (Sphingidae, Notodontidae, Noctuidae, Arctiidae, Geometridae, Hyblaeidae, Cossidae). Journal of the Lepidoptera Society 56:9-44. 
Benjamin FH. 1922. Early stages of Noropsis

hieroglyphica Cram. (Lepidoptera, Noctuidae).

Entomological News 33: 277-278

Collins CT, Watson A. 1983. Field observations of bird predation on neotropical moths. Biotropica 15:53-60.

Covell Jr CV. 1984. A Field Guide to Moths of Eastern North America. Houghton Mifflin Co.

Boston, MA.

Drees BM, Rice ME. 1990. Population dynamics and seasonal occurrence of soybean insect pests in southeastern Texas USA. Southwestern Entomologist 15:49-56.

Dyer LA. 1997. Effectiveness of caterpillar defenses against three species of invertebrate predators. Journal of Research on the Lepidoptera 34:48-68.

Florida Bureau of Entomology. 1983. Insects affecting ornamentals. Tri-ology 22: 7-8.

Heppner JB. 2003. Lepidoptera of Florida. Arthropods of Florida and Neighboring Land Areas Vol. 17. Florida Department of Agriculture and Consumer Services, Division of Plant Industry, Gainesville, FL.

Holland WJ. 1903. The Moth Book: a Popular Guide to a Knowledge of the Moths of North America. Doubleday, Page and Co. New York.

Lubeck GM, Oliveira JV, de Almeida RP. 1995. Faunistic analysis of Lepidoptera collected in two agricultural communities of the Mata Norte area of Pernambuco. Anais do Sociedade Entomologica do Brazil 24: 353-370.

Poole RW. 1989. Noctuidae part I. In Heppner JB (ed.) Lepidopterorum Catalogus (new series). E.J. Brill/Flora \&Fauna Publications, New York.

Watson A, Whalley PES. 1975. The Dictionary of Butterflies and Moths in Color. McGraw-Hill Book Co. New York.

Zhang BC. 1994. Index of Economically Important Lepidoptera. CAB International, Wallingford, UK. 